\title{
Study on the fatty acid profile of phospholipid and neutral lipid in Hanwoo beef and their relationship to genetic variation
}

\author{
Seok-Hyeon Beak ${ }^{1 \dagger}$, Yoonseok Lee ${ }^{2}$, Eun Bi Lee ${ }^{3}$, Kyoung Hoon Kim ${ }^{1,3}$, Jong Geun Kim³ ${ }^{1,3}$, Jin Duck Bok ${ }^{3}$ \\ and Sang-Kee Kang ${ }^{1,3,4^{*}}$ \\ ${ }^{1}$ Graduate School of International Agricultural Technology, Seoul National University, Pyeongchang 25354, Korea \\ ${ }^{2}$ Department of Biotechnology, College of Agriculture \& Life Science, HanKyong National University, Anseong 17579, Korea \\ ${ }^{3}$ Institute of Eco-friendly Economic Livestock, Institute of Green-Bio Science \& Technology, Seoul National University, Pyeongchang \\ 25354, Korea \\ ${ }^{4}$ Research Institute of Agriculture and Life Science, Seoul National University, Seoul 08826, Korea
}

\begin{abstract}
Maize which has very high omega- 6 fatty acid content has been used as a main feed grain for Hanwoo beef production to increase marbling, and thus omega- 6 to omega-3 fatty acids ratio in Hanwoo beef is expected to be biased. To elucidate the current status of omega fatty acids ratio in Hanwoo beef, fatty acid profiles of neutral lipid and phospholipid fraction were analyzed separately using 55 Hanwoo steers' longissimus dorsi muscle slaughtered at Pyeongchang, Korea from Oct. to Nov. 2015. In addition, an association study was conducted to evaluate associations between single nucleotide polymorphism (SNP) markers from references and omega fatty acid profiles in phospholipid of Hanwoo beef samples using analysis of variance (ANOVA). In neutral lipid fraction, composition of saturated and monounsaturated fatty acids was higher and polyunsaturated fatty acids was lower compared to those in phospholipid fraction. The mean n-6/n-3 ratios of Hanwoo were $56.059 \pm 16.180$ and $26.811 \pm 6.668$ in phospholipid and neutral lipid, respectively. There were three SNPs showing statistically significant associations with omega fatty acid content. GA type of rs41919985 in fatty acid synthase (FASN) was significantly associated with the highest amount of C20:5 n-3 $(p=0.031)$. CC type of rs41729173 in fatty acid-binding protein 4 (FABP4) was significantly associated with the lowest amount of C22:2n-6 $(p=0.047)$. AG type of rs42187261 in FADS1 was significantly linked to the lowest concentration of $C 20: 4 n-6(p=0.044)$. The total $n-6 / n-3$ ratio of the steer which has all four SNP types in above loci (27.905) was much lower than the mean value of the total $n-6 / n-3$ ratio in phospholipid of the 55 Hanwoo steers $(56.059 \pm 16.180)$. It was found that phospholipid and neutral lipid of Hanwoo have very high $n-6 / n-3$ ratios compared to the reported data from different cow breeds. Four SNPs in genes related with fatty acid metabolism showed significant associations with the fatty acid profile of phospholipid and may have potential as SNP markers to select Hanwoo steers in terms of $n-6 / n-3$ balance in the future.
\end{abstract}

Keywords: Association study, Fatty acids profile, Hanwoo, Omega fatty acids, Single nucleotide polymorphism

Received: Dec 12,2018 Revised: Mar 11,2019 Accepted: Mar 11,2019

${ }^{\dagger}$ Current affiliation: Department of Agricultural Biotechnology and Research Institute of Agriculture and Life Sciences, College of Agriculture and Life Sciences, Seoul National University, Seoul 08826, Korea.

"Corresponding author: Sang-Kee Kang, Graduate School of International Agricultural Technology, Seoul National University, Pyeongchang 25354, Korea. Tel: +82-33-339-5731,E-mail: kangsk01@snu.ac.kr

This is an Open Access article distributed under the terms of the Creative Commons Attribution Non-Commercial License (http://creativecommons.org/licenses/bync/4.0/) which permits unrestricted non-commercial use, distribution, and reproduction in any medium, provided the original work is properly cited.

Copyright (C) 2019 Korean Society of Animal Science and Technology. 


\section{Background}

Modern diets have a high level of imbalance in omega fatty acids comparing to prehistoric diets because of too much intake of several grains rich in omega-6 fatty acids and modern animal husbandry based on the grain-fed system, and it makes people get chronic diseases such as cardiovascular disease, autoimmune disease, etc. [1]. Especially, Hanwoo beef grading system is based on high marbling score which is achieved by feeding mainly grains such as corn which is high in omega- 6 fatty acids. Consequently, Hanwoo beef may have highly biased $n-6 / n-3$ fatty acids ratio [2].

In order to balance the ratio of beef omega fatty acids towards lowering n-6 to n-3 fatty acid ratio, two strategies are usually used. The first one is feeding additives which are high in $\mathrm{n}-3$ fatty acids. However, the ruminal bacteria in the rumen hydrogenate polyunsaturated fatty acids (PUFA) so that fatty acids fed to the ruminants are changed into various fatty acids in the rumen and are hard to be absorbed as the original form [3]. The second one may be finding genetic polymorphisms which balance omega fatty acids ratio. The amount of omega fatty acids is higher in phospholipid than neutral lipid, and phospholipid is the building blocks of the cell membrane and its fatty acids composition is mainly controlled by the genes related to fatty acid metabolism, but fatty acids composition of neutral lipid is mainly influenced by the diet [4]. Thus, the fatty acid compositions of phospholipid and neutral lipid are very different each other [5].

There have been many studies on single nucleotide polymorphisms (SNPs) for enhancing beef quality such as marbling score and fatty acids composition. FABP4 (fatty acid-binding protein 4), FASN (fatty acid synthase) and SCD (stearoyl-CoA desaturase) are the representative genes related to meat quality. The SNP, rs41729173 in FABP4 is in 3' untranslated region and was related to fatty acid composition, especially linoleic acid (C18:2 n-6), arachidonic acid (C20:4 n-6, AA), eicosapentaenoic acid (C20:5 n-3) and docohexaenoic acid (C22:6 n-3) [6]. In the case of FASN, rs41919985 is a missense SNP which has a significant relationship with lower C20:3 n-6 in beef [7] and also significantly associated with marbling score [8]. The rs41255693 in SCD showed a significant effect on monounsaturated fatty acid (MUFA) content and the melting point in intramuscular fat [7,9].

Three SNPs (rs136261927, rs42187261, rs109772589) in FADS (fatty acid desaturase) gene cluster were found to have significant associations with three milk PUFAs, C20:3 n-6, C20:4 n-6 and C20:5 n-3. Two SNPs, rs136261927 and rs42187261 in FADS1 are linked to C20:3 n-6 and C20:4 n-6, and C 20:5 n-3 contents, respectively. The rs109772589 in FADS2 is also associated with C20:3 n-6 and C20:4 n-6 levels [10].

In this study, the fatty acid profiles including omega fatty acids ratio of Hanwoo beef was analyzed separately on phospholipid and neutral lipid, and the associations were analyzed between omega fatty acids content of phospholipid and the genotypes of SNPs in the genes related to fatty acid metabolism.

\section{Materials and Methods}

\section{Beef samples, carcass grades, and sampling part for} fatty acid analysis

The beef samples of 55 Hanwoo steers were collected from Oct. to Nov. 2015 at Pyeongchang province, Korea. The steers were from seven farms grown under three feeding programs. All steers were slaughtered in a local municipal slaughterhouse (Pyeongchang, Korea) at $925 \pm 26 \mathrm{~d}$ of age with an average carcass weight of 458 $\pm 46 \mathrm{~kg}$.

Top round (Semimembranosus, TR) was used for fatty acid analysis because TR has the lower intramuscular fat and the higher proportion of phospholipid which has more PUFA than neutral lipid [5]. The TR samples were collected and stored at $-80^{\circ} \mathrm{C}$ after slaughter. To analyze the association between fatty acid composition of beef and the genotypes of SNPs in the genes related to fatty acid metabolism, phospholipid fraction is better because the neutral fat composition is greatly affected by diet $[4,11]$.

\section{Fatty acids profile of phospholipid}

\section{Separation of phospholipid and neutral lipid from beef and fatty acid analysis}

Folch method [12] was used for extracting total lipid with minor modifications $[13,14]$, and lipid extractions were performed in triplicate. $2 \mathrm{~g}$ of the chopped beef sample from longissimus thoracis between $12^{\text {th }}$ and $13^{\text {th }}$ rib was put into a glass tube with $20 \mathrm{~mL}$ of Folch solvent, a mixture of chloroform/methanol $(2: 1, \mathrm{v} / \mathrm{v})$, and $150 \mu \mathrm{L}$ of $10 \%$ butylated hydroxyanisole, and homogenized at 10,000 rpm for $1 \mathrm{~min}$ (IKA, Germany). The homogenate was incubated at room temperature for 30 min with rocking at 50 rpm, and filtered through filter paper (Whatman \# 6, USA) into a new glass tube with $4 \mathrm{~mL}$ of $0.9 \% \mathrm{NaCl}$ solution. The solution was incubated again as above and centrifuged at 5,182 $\times \mathrm{g}(\mathrm{rcf})$ for $10 \mathrm{~min}$. The upper aqueous phase was removed by aspiration and organic solvent phase was condensed under nitrogen gas (99.99\%) at $40^{\circ} \mathrm{C}$ and $20 \mathrm{psi}$ for $1 \mathrm{~h}$. The lipids were dissolved in $250 \mu \mathrm{L}$ of chloroform and stored at $-20^{\circ} \mathrm{C}$.

Lipids were separated by thin-layer chromatography (TLC). TLC plate (Merck, Germany) was pre-run with chloroform/methanol $(1: 1, \mathrm{v} / \mathrm{v})$ and dried in a fume hood. $80 \mu \mathrm{L}$ of lipid was spotted on the plate at $2.5 \mathrm{~cm}$ from the bottom, and TLC was run with diethyl ether/methanol /acetic acid (90:1:1, v/v) until solvent reached $10 \mathrm{~cm}$ under the plate end. The plate was dried in a fume hood and 
lipids were visualized by spraying the primuline (Sigma-Aldrich, Germany) solution with a glass atomizer. The primuline solution was prepared by dissolving $100 \mathrm{mg}$ of primuline in $200 \mathrm{~mL}$ of acetone/water mixture $(4: 1, \mathrm{v} / \mathrm{v})$. The plate was dried in an oven at $55^{\circ} \mathrm{C}$ for $2 \mathrm{~min}$. Under UV light (340 nm), phospholipid stays on the loading spot and neutral lipid is moved with the solvent line.

Direct methylation method [15] was used for methylation. Phospholipid and neutral lipid spots were scraped from the silica pate, and put into two glass tubes with $530 \mu \mathrm{L}$ methanol and 70 $\mu \mathrm{L}$ of $10 \mathrm{~N}$ potassium hydroxide respectively. After that, the tubes were incubated in a water bath at $55^{\circ} \mathrm{C}$ for 90 min with short vortex every $20 \mathrm{~min}$. The tubes were cooled to ambient temperature and $58 \mu \mathrm{L}$ of $24 \mathrm{~N}$ sulfuric acid was added. The tubes were incubated and cooled again as above. $500 \mu \mathrm{L}$ of hexane was added to the tubes, vortexed for $5 \mathrm{~min}$ and centrifuged at $5,182 \times \mathrm{g}(\mathrm{rcf})$ for 5 min. Upper phase (hexane) was transferred to GC-vials (Agilent, USA).

\section{Conditions of gas chromatography}

Fatty acid was analyzed by gas chromatography with flame ionization detector (GC-FID, Agilent 7890B, USA). The column was SP-2560 (ID 0.25 mm×length 100 m; Sigma-Aldrich, Germany), and fatty acid methyl ester 37 (FAME 37, Sigma-Aldrich, Germany) was used as a reference for peak identification and quantification. The running condition of GC-FID was followed by the FAME 37 manual (oven temperature: $140^{\circ} \mathrm{C}$ for $5 \mathrm{~min}$; Ramp: $240^{\circ} \mathrm{C}$ at $4^{\circ} \mathrm{C} / \mathrm{min}$ and hold for $28 \mathrm{~min}$; injector and detector temperature: $260^{\circ} \mathrm{C}$; split ratio: $1: 30$; injection volume: $1 \mu \mathrm{L}$ ).

Retention time and area value of each fatty acid peak, and peak pattern of the sample were obtained. Peak was identified comparing with FAME 37 peak pattern. These data were processed for association analysis between fatty acid composition and the genotype.

\section{Genomic DNA extraction}

Genomic DNA (gDNA) was extracted using Ghatak's method with minor modification [16]. $25 \mathrm{mg}$ of beef samples were chopped and placed in a $1.5 \mathrm{~mL}$ microtube with $300 \mu \mathrm{L}$ of tissue lysis buffer (10 mM Tris-HCl, $10 \mathrm{mM}$ EDTA, $100 \mathrm{mM} \mathrm{NaCl}, 2 \%$ SDS, $\mathrm{pH}$ 7.5). $5 \mu \mathrm{L}$ of $20 \mathrm{mg} / \mathrm{mL}$ proteinase K (Biosesang, Korea) and $20 \mathrm{mg} / \mathrm{mL}$ RNase A (Thermo Fisher, USA) were added to the tube, and the tube was incubated at $56^{\circ} \mathrm{C}$ for around $3 \mathrm{~h}$ with occasional gentle inverting until the beef sample is completely melted. To the tube $300 \mu \mathrm{L}$ of $7 \mathrm{M}$ ammonium acetate was added, gently inverted several times, and centrifuged at 15,815 $\times \mathrm{g}(\mathrm{rcf})$ and $20^{\circ} \mathrm{C}$ for $15 \mathrm{~min} .600 \mu \mathrm{L}$ of the supernatant was transferred to a new $1.5 \mathrm{~mL}$ tube, same volume of 2-propanl (Merck, Germany) was added into the tube, and chilled at $-20^{\circ} \mathrm{C}$ for $1 \mathrm{~h}$. The tube was centrifuged at $15,815 \times \mathrm{g}(\mathrm{rcf})$ and $4^{\circ} \mathrm{C}$ for $10 \mathrm{~min}$. The pellet was washed with $250 \mu \mathrm{L}$ of $70 \%$ ethanol (Merck, Germany) and dried at room temperature. gDNA was dissolved in $50 \mu \mathrm{L}$ of TE buffer and stored at $-20^{\circ} \mathrm{C}$ until use.

\section{PCR and genotyping}

The six SNPs were chosen in the five genes which were reported for their relation with fatty acid metabolism from the references to test the association with omega fatty acids content; rs41919985 in FASN, rs41255693 in SCD, rs41729173 in FABP4, rs42187261 and rs136261927 in FADS1 and rs109772589 in FADS2 [6,7,10]. Primers were designed using NCBI Primer-BLAST [17]. The primer pairs were synthesized (Bioneer, Korea) and dissolved in TE buffer at $10 \mathrm{pmol} / \mu \mathrm{L}$.

Restriction fragment length polymorphism (RFLP) was conducted to identify the SNP genotypes for five SNPs (rs41919985, rs41255693, rs41729173, rs136261927, and rs109772589), and DNA sequencing (Macrogen, Korea) was used for one SNP (rs42187261) due to the lack of available restriction enzyme site for the SNP typing. Hot start PCR premix with dye (Biofact, Korea) was used for PCR following the manufacturer's manual. PCR conditions were as follow: $5 \mathrm{~min}$ at $95^{\circ} \mathrm{C}, 35$ cycles of $30 \mathrm{~s}$ at $95^{\circ} \mathrm{C}, 30$ $\mathrm{s}$ at each melting temperature of primer pairs and $1 \mathrm{~min}$ at $72^{\circ} \mathrm{C}$, followed by $5 \mathrm{~min}$ at $72^{\circ} \mathrm{C}$, and ended at $4^{\circ} \mathrm{C}$.

After PCR, restriction enzyme digestion was conducted to type SNP, and proper enzymes for each SNP were searched by using NEB cutter V2.0 program [18]. Restriction enzyme digestion was carried out following the manufacturer's condition. The products of restriction enzyme digestion were observed on $2 \%$ agarose gel using SEKEM LE agarose (Lonza, Switzerland), 0.5×TBE buffer (Biosesang, Korea) and Eco staining solution (Biofact, Korea). 5 $\mu \mathrm{L}$ of restriction enzyme digestion products and 100 bp size marker (Biofact, Korea) were loaded, electrophoresis was run for 25 $\min$ at $100 \mathrm{~V}$, and gels were analyzed using Chemi-Doc (Bio-Rad, USA). The detailed information of primers, restriction enzymes, and restriction fragments for each SNP are shown in Table S1 (Additional file 1).

\section{Statistical analysis}

The Hardy-Weinberg equilibrium (HWE) was tested for each locus by comparing expected and observed genotype frequencies through the Chi-square statistic. In order to evaluate the association between omega fatty acid composition and six SNPs within five genes, the statistical program, SPSS v. 22 (IBM, USA) was used for one-way ANOVA [19]. 


\section{Results and Discussion}

The fatty acid compositions of neutral lipid and phospholipid in longissimus dorsi muscle of Hanwoo beef The fatty acid composition of phospholipid and neutral lipid in longissimus dorsi muscle of 55 Hanwoo steers were separately analyzed with GC-FID. Mean, standard deviation, maximum and minimum values for individual fatty acid percentage of the Hanwoo muscle are shown in Table 1 . The fatty acid profiles of phospholipid and neutral lipid fractions were very different. Mean concentration of saturated fatty acid (SFA) and MUFA in neutral lipid (38.2\% and 59\%, respectively) was higher than in phospholipid (28.5\% and 21.5\%, respectively). On the contrary, PUFA was much higher in phospholipid fraction (50\%) than neutral lipid one (2.8\%). Phospholipid is a building block of cell membrane, is strictly regulated under genetic control. Neutral lipid fraction is stored in lipid droplet of adipose tissue as energy source, and mainly affected by diet [4]. Buchanan et al. [5] also showed that triacylglycerol fraction of intramuscular fat from Angus cattle included higher SFA and MUFAs, and lower PUFAs compared

Table 1. Descriptive statistic for fatty acid composition of the 55 beef samples

\begin{tabular}{|c|c|c|c|c|c|c|}
\hline \multirow[b]{2}{*}{ FA (\%) } & \multicolumn{3}{|c|}{ Phospholipid } & \multicolumn{3}{|c|}{ Neutral lipid } \\
\hline & Mean \pm SD & Max & Min & Mean \pm SD & Max & Min \\
\hline C14:0 & $0.259 \pm 0.385$ & 2.935 & 0.105 & $3.212 \pm 1.030$ & 5.470 & 0.007 \\
\hline $\mathrm{C} 14: 1$ & $0.009 \pm 0.027$ & 0.148 & 0 & $1.531 \pm 0.682$ & 2.900 & 0.238 \\
\hline $\mathrm{C} 15: 0$ & $0.161 \pm 0.059$ & 0.367 & 0.081 & $0.295 \pm 0.055$ & 0.501 & 0.182 \\
\hline C15:1 & $0.775 \pm 0.297$ & 1.328 & 0.180 & - & - & - \\
\hline C16:0 & $13.175 \pm 2.277$ & 23.950 & 10.016 & $25.351 \pm 3.147$ & 30.269 & 18.773 \\
\hline $\mathrm{C} 16: 1$ & $1.363 \pm 0.683$ & 5.503 & 0.604 & $6.794 \pm 1.730$ & 11.166 & 3.001 \\
\hline $\mathrm{C} 17: 0$ & $0.304 \pm 0.152$ & 1.318 & 0.149 & $0.652 \pm 0.118$ & 0.885 & 0.392 \\
\hline C17:1 & $0.134 \pm 0.075$ & 0.313 & 0 & $0.831 \pm 0.181$ & 1.486 & 0.442 \\
\hline C18:0 & $14.236 \pm 1.627$ & 18.460 & 8.883 & $8.127 \pm 1.553$ & 15.276 & 5.631 \\
\hline C18:1n9t & $0.391 \pm 0.176$ & 1.111 & 0.135 & $1.025 \pm 0.449$ & 2.100 & 0 \\
\hline C18:1n9c & $18.670 \pm 5.315$ & 41.634 & 10.942 & $48.487 \pm 4.094$ & 57.087 & 41.879 \\
\hline $\mathrm{C} 18 \mathrm{a} 2 \mathrm{n} 6 \mathrm{c}$ & $28.941 \pm 4.547$ & 35.776 & 8.092 & $2.390 \pm 0.839$ & 4.199 & 1.424 \\
\hline $\mathrm{C} 20: 0$ & $0.135 \pm 0.137$ & 0.956 & 0 & $0.058 \pm 0.016$ & 0.112 & 0.038 \\
\hline C18:3n6 & $0.254 \pm 0.119$ & 0.617 & 0.121 & $0.026 \pm 0.016$ & 0.0745 & 0 \\
\hline C20:1n9 & $0.197 \pm 0.072$ & 0.420 & 0.049 & $0.370 \pm 0.121$ & 0.738 & 0.187 \\
\hline C18:3n3 & $0.400 \pm 0.100$ & 0.701 & 0.163 & $0.095 \pm 0.024$ & 0.158 & 0.052 \\
\hline $\mathrm{C} 21: 0$ & $0.198 \pm 0.113$ & 0.909 & 0.086 & $0.440 \pm 0.085$ & 0.672 & 0.289 \\
\hline $\mathrm{C} 20: 2 \mathrm{n} 6$ & $0.272 \pm 0.124$ & 0.774 & 0.121 & $0.044 \pm 0.028$ & 0.159 & 0 \\
\hline $\mathrm{C} 22: 0$ & - & - & - & $0.014 \pm 0.011$ & 0.049 & 0 \\
\hline $\mathrm{C} 20: 3 \mathrm{n} 6$ & $5.055 \pm 1.113$ & 6.904 & 0.142 & $0.110 \pm 0.040$ & 0.248 & 0.051 \\
\hline $\mathrm{C} 22: 1 \mathrm{n} 9$ & $0.013 \pm 0.022$ & 0.094 & 0 & $0.012 \pm 0.009$ & 0.049 & 0 \\
\hline $\mathrm{C} 20: 3 \mathrm{n} 3$ & $0.098 \pm 0.029$ & 0.160 & 0 & $0.006 \pm 0.014$ & 0.103 & 0 \\
\hline $\mathrm{C} 20: 4 \mathrm{n} 6$ & $14.386 \pm 2.764$ & 19.651 & 3.652 & $0.111 \pm 0.078$ & 0.541 & 0.040 \\
\hline $\mathrm{C} 22: 2 \mathrm{n} 6$ & $0.108 \pm 0.033$ & 0.174 & 0 & $0.007 \pm 0.007$ & 0.045 & 0 \\
\hline $\mathrm{C} 24: 0$ & $0.005 \pm 0.014$ & 0.071 & 0 & $0.011 \pm 0.027$ & 0.173 & 0 \\
\hline $\mathrm{C} 20: 5 \mathrm{n} 3$ & $0.332 \pm 0.228$ & 1.576 & 0.065 & $0.001 \pm 0.001$ & 0.007 & 0 \\
\hline $\mathrm{C} 22: 6 \mathrm{n} 3$ & $0.129 \pm 0.235$ & 1.795 & 0 & - & - & - \\
\hline SFA & $28.473 \pm 1.634$ & 40.115 & 25.762 & $38.159 \pm 3.523$ & 46.034 & 31.937 \\
\hline MUFA & $21.552 \pm 5.903$ & 48.933 & 5.017 & $59.051 \pm 3.114$ & 64.920 & 51.566 \\
\hline PUFA & $49.975 \pm 6.789$ & 57.697 & 13.899 & $2.790 \pm 0.944$ & 4.967 & 1.668 \\
\hline Total n6 & $49.016 \pm 6.632$ & 2.753 & 0.440 & $2.687 \pm 0.921$ & 0.261 & 0.052 \\
\hline Total n3 & $0.959 \pm 0.388$ & 56.477 & 13.418 & $0.103 \pm 0.033$ & 4.706 & 1.615 \\
\hline $\mathrm{n} 6 / \mathrm{n} 3$ & $56.059 \pm 16.180$ & 95.366 & 18.700 & $26.811 \pm 6.668$ & 43.679 & 17.448 \\
\hline
\end{tabular}

FA, fatty acid; SD, standard deviation; Max, maximum value; Min, minimum value; t, trans; c, cis; SFA, saturated fatty acid; MUFA, mono unsaturated fatty acid; PUFA, poly unsaturated fatty acid. 
to phospholipid fraction. In phospholipid, the average n-6 to n-3 ratio was $56.059 \pm 16.180$, and maximum and minimum value were 95.366 and 18.700 , respectively. The average, maximum and minimum value of $n-6 / n-3$ in neutral lipid were $26.811 \pm 6.668$, 43.679 and 17.448, respectively. Daley et al. [2] reported a review article comparing fatty acids profiles between grass-fed and grainfed beef. The highest and the lowest $n-6 / n-3$ ratio of 3.72:1 and 1.44:1 in grass-fed beef were lower than the ratios in grain-fed beef of 13.6:1 and 3:1, respectively. Comparing to these reports, the average omega fatty acids ratios in phospholipid and neutral lipid of 55 Hanwoo (56:1 and 27:1, respectively) were greatly biased towards high $n-6$ content mainly due to the long finishing program for high marbling using corn-based diet.

Pearson's correlation analysis among fatty acid compositions of the 55 Hanwoo beef samples (Table S2). The correlation coefficient among omega fatty acids was low or moderate. C18:3 n-3 had moderately positive correlation with C18:2 n-6 and C20:4 n-6 ( $r=$ 0.491 and 0.414 respectively, $p<0.05)$. C18:3 n-3 had moderately positive correlation with C18:2 n-6 and C20:4 n-6 ( $r=0.491$ and 0.488 respectively, $p<0.05)$. The correlation coefficient between C18:2 n-6 and C20:4 n-6 was 0.414 ( $p<0.05)$. C18:3 n-3 and C18:2 n-6 are essential fatty acids and start points of omega fatty acid synthesis pathway, and C18:2 n-6 is a one of precursors of C20:4 n-6 [20]. The increase in C18:2 n-6 fatty acid intake will increase the amount of C20:4 n-6 fatty acid. However, more research is needed to clarify the correlation between C18:2 n-6 and C20:4 n-6, and C18:3 n-3.

\section{SNP marker genotypes of beef samples}

The frequencies and benefit verification of the genotypes as a marker in the 55 samples are shown in Table 2. In the case of rs109772589 (FADS2) genotype, all 55 samples had the same 'GA' heterogenotype. Thus, this SNP was excluded from association analysis. The enzyme, FADS2 is the initial and rate-limiting enzyme of omega fatty acid metabolic pathway. Therefore, rs109772589 still may have potential as a genetic marker for omega fatty acid balance, but for this analysis more beef samples with genetic variance will be needed. The frequencies of rs41919985 in FASN were 0.70 and 0.30 for GG and GA genotypes, respectively. The count of $\mathrm{G}$ allele was 95 and $\mathrm{A}$ allele was 17. In the current study, there were only two genotypes in rs41919985 in FASN. Frequencies of rs41919985 minor allele, 'A' were reported as very low in Korean native cattle, Hanwoo as 0.12 and 0.16 , respectively $[8,21]$. We assumed that is because of breeding focused on marbling score. The frequencies of rs 41255693 in SCD were 0.23, 0.57, and 0.20 for TT, TC, and CC genotypes, respectively. The count of $\mathrm{T}$ allele was 58 and $\mathrm{C}$ allele was 54 . In the case of rs41729173 in FABP4, the frequencies were $0.59,0.34$, and 0.07 for $\mathrm{CC}, \mathrm{CG}$ and GG genotypes, respectively. Lastly, the frequencies of rs136261927 and rs42187261 in FADS1 were 0.30, 0.41 and 0.29 for GG, GA, and $A A$, and $0.52,0.38$, and 0.11 for AA, AG and GG respectively. In Hanwoo population ( $\mathrm{n}=55)$, all SNPs are in HWE and have a MAF (> 5\%) (Table 2). A MAF threshold of 5\% is common in research on human genetics because SNP with lower frequency require substantially greater sample sizes to detect small effects, which are typical for complex traits [22]. So, this results showed that all SNP are polymorphic.

Table 2. The genotype, allele and minor allele frequency, and HWE for six candidate SNPs used in this study

\begin{tabular}{|c|c|c|c|c|c|c|c|}
\hline SNP (gene) & Allele (n) & Frequency & Genotype (n) & Frequency & MAF & $\mathbf{H}$ & HWE \\
\hline \multirow{3}{*}{$\begin{array}{l}\text { rs41919985 } \\
\text { (FASN) }\end{array}$} & G (95) & 0.85 & GG (39) & 0.70 & 0.15 & 0.26 & 0.18 \\
\hline & $A(17)$ & 0.15 & GA (17) & 0.30 & & & \\
\hline & - & - & $\mathrm{AA}(0)$ & 0.00 & & & \\
\hline \multirow{3}{*}{$\begin{array}{l}\text { rs } 41255693 \\
\text { (SCD) }\end{array}$} & $\mathrm{T}(58)$ & 0.52 & $\mathrm{TT}(13)$ & 0.23 & 0.48 & 0.50 & 0.28 \\
\hline & $C(54)$ & 0.48 & TC (32) & 0.57 & & & \\
\hline & - & - & CC (11) & 0.20 & & & \\
\hline \multirow{3}{*}{$\begin{array}{l}\text { rs41729173 } \\
\text { (FABP4) }\end{array}$} & $C(85)$ & 0.76 & CC (33) & 0.59 & 0.24 & 0.37 & 0.59 \\
\hline & $\mathrm{G}(27)$ & 0.24 & CG (19) & 0.34 & & & \\
\hline & - & - & GG (4) & 0.07 & & & \\
\hline \multirow{3}{*}{$\begin{array}{l}\text { rs136261927 } \\
\text { (FADS1) }\end{array}$} & G (57) & 0.51 & GG (17) & 0.30 & 0.49 & 0.50 & 0.18 \\
\hline & $A(55)$ & 0.49 & GA (23) & 0.41 & & & \\
\hline & - & - & $\mathrm{AA}(16)$ & 0.29 & & & \\
\hline \multirow{3}{*}{$\begin{array}{l}\text { rs42187261 } \\
\text { (FADS1) }\end{array}$} & $A(79)$ & 0.71 & $\mathrm{AA}(29)$ & 0.52 & 0.29 & 0.42 & 0.46 \\
\hline & G (33) & 0.29 & $A G(21)$ & 0.38 & & & \\
\hline & - & - & GG (6) & 0.11 & & & \\
\hline
\end{tabular}

SNP, single nucleotide polymorphism; n, number of animals; MAF, minor allele frequency; $\mathrm{H}$, heterozygosity; HWE, probability value of Hardy-Weinberg equilibrium; FASN, fatty acid synthase; SCD, stearoyl-CoA desaturase; FABP, fatty acid binding protein; FADS, fatty acid desaturase. 
Relationship between SNP genotypes and fatty acid composition of phospholipid

The association between the mean composition of fatty acids and the SNP types were analyzed using ANOVA. The selected data of which $p$-values are $<0.05$ in the association analysis of fatty acid composition with SNP genotypes are shown in Table 3. GA type of rs41919985 in FASN was significantly associated with the higher proportion of C20:5 n-3 ( $p=0.031)$. However, AA type of rs41919985 was not observed in the samples. Therefore, further study should be conducted with more samples to confirm the effects of rs41919985. CC type of rs41729173 in FABP4 was significantly associated with the lowest amount of $\mathrm{C} 22: 2 \mathrm{n}-6$ ( $p=$ 0.047), and AG type of rs42187261 in FADS1 was significantly associated the lowest amount of C20:4 n-6 ( $p=0.044)$. GA type of rs136261927 in FADS1 was significantly associated with lowest ratio of $\mathrm{C} 20: 3 \mathrm{n}-6$ to $\mathrm{C} 20: 4 \mathrm{n}-6$ ( $p=0.027)$.

The rs42187261 and rs136261927 in FADS1 were significantly associated with the content of C20:4 n- 6 and the ratio of C20:3 $\mathrm{n}-6$ to $\mathrm{C} 20: 4 \mathrm{n}-6$, respectively. FADS1 is the enzyme which converts $\mathrm{C} 20: 3 \mathrm{n}-6$ to $\mathrm{C} 20: 4 \mathrm{n}-6$. Therefore, it is reasonable that the different SNP groups have different mean values of $\mathrm{C} 20: 3 \mathrm{n}-6$ and C20:4 n-6.

The significant association results between genotypes and fatty acid composition were compared with reported data from references (Additional file 1: Table S3). Significant associations of AA genotype of rs41919985 in FASN and CC genotype of rs41255693 in SCD were reported with lower concentrations of C20:3n-6 in comparison with GG genotype and lower concentrations $\mathrm{C} 20: 2 \mathrm{n}-6$ in comparison with TT genotype $(p<0.05)$, respectively [7].

In Aberdeen Angus beef, GG type of rs41729173 in FABP4 was significantly associated with the highest amount of $\mathrm{C} 18: 2 \mathrm{n}-6$ $(p=0.031)$ and total $\mathrm{n}-6$ fatty acids $(p=0.03)$. For Blonde d'Aquitaine beef, CC type of rs41729173 in FABP4 was significantly associated with the highest amount of C20:4 n-6 ( $p=0.044), C 20: 5$ $\mathrm{n}-3(p=0.044)$ and total $\mathrm{n}-3$ fatty acids $(p=0.044)$ [6].

AA type of rs42187261 and GG type of rs136261927 in FADS1 was also significantly linked to the highest increase in milk C20:5 n-3 ( $p=0.004)$ and C20:3 n-6 ( $p=0.0003)$, respectively [10].

However, in this study all the association data mentioned above did not show the significant relations having much higher $p$-values than 0.05 except rs136261927 in FADS1 $(p=0.044)$. Besides, most data had a different tendency with the references. It may be due to the sample size, lipid source (phospholipid vs. total lipid), or genetic characteristics of Hanwoo. In terms of sample size, Dujkoba's analysis was conducted with seventeen samples of Aberdeen Angus beef and sixteen samples of Blonde d'Aquitaine beef, and GG type of rs41729173 in FABP4 was only one in Blonde d'Aquitaine beef. Thus these association results are hardly conclusive.

The data in Table S4 (Additional file 1) shows certain allele effect though $p$-values were higher than 0.05 , and association was not mentioned in the references. This study and the references were conducted with the different breed of cow and lipid (phospholipid vs. total lipid). Therefore, different results can be possible. In the total lipid, proportion of phospholipid is greatly affected by intramuscular fat content, a main source of neutral lipid. The fatty acid profiles are greatly different between phospholipid and neutral lipid. Moreover, only omega fatty acids of phospholipid are affected by animal genetics and metabolism, and neutral lipids are mainly from the diet. Thus, these associations should be confirmed by further analysis using phospholipid from more samples.

Table 3. The association between genotypes and omega fatty acid composition with $p$-value less than 0.05

\begin{tabular}{|c|c|c|c|c|c|}
\hline SNP (gene) & Fatty acid & SNP type & $\mathbf{n}$ & Mean (\%) & $p$-value \\
\hline \multirow{3}{*}{$\begin{array}{l}\text { rs4191999859 } \\
\text { (FASN) }\end{array}$} & \multirow[t]{3}{*}{$C 20: 5 n-3$} & GA & 17 & $0.430 \pm 0.082$ & \multirow[t]{3}{*}{0.031} \\
\hline & & GG & 38 & $0.288 \pm 0.023$ & \\
\hline & & - & - & - & \\
\hline \multirow{3}{*}{$\begin{array}{l}\text { rs41729173 } \\
\text { (FABP4) }\end{array}$} & \multirow[t]{3}{*}{$C 22: 2 n-6$} & GG & 3 & $0.099 \pm 0.019$ & \multirow[t]{3}{*}{0.047} \\
\hline & & CG & 19 & $0.123 \pm 0.005$ & \\
\hline & & $\mathrm{CC}$ & 33 & $0.100 \pm 0.006$ & \\
\hline \multirow{3}{*}{$\begin{array}{l}\text { rs42187261 } \\
\text { (FADS1) }\end{array}$} & \multirow[t]{3}{*}{ C20:4 n-6 } & AA & 28 & $14.884 \pm 0.437$ & \multirow[t]{3}{*}{0.044} \\
\hline & & $A G$ & 21 & $13.282 \pm 0.690$ & \\
\hline & & GG & 6 & $15.929 \pm 0.847$ & \\
\hline \multirow{3}{*}{$\begin{array}{l}\text { rs136261927 } \\
\text { (FADS1) }\end{array}$} & \multirow[t]{3}{*}{$C 20: 3 n-6 / C 20: 4$ n-6 } & AA & 15 & $0.392 \pm 0.018$ & \multirow[t]{3}{*}{0.027} \\
\hline & & GA & 23 & $0.323 \pm 0.021$ & \\
\hline & & GG & 17 & $0.381 \pm 0.020$ & \\
\hline
\end{tabular}

SNP, single nucleotide polymorphism; n, number of animals; FASN, fatty acid synthase; FABP, fatty acid binding protein; FADS, fatty acid desaturase. 


\section{Conclusion}

Fatty acid profiles in phospholipid and neutral lipid of the 55 Hanwoo beef were analyzed, which showed very high $n-6 / n-3$ ratios compared to the reported values from different breeds. It seems that a proper way to adjust this imbalance of omega fatty acids in Hanwoo beef may be necessary. An association analysis was carried out between some SNP markers and omega fatty acids in phospholipid of the 55 Hanwoo beef. GA type of rs41919985 in FASN was significantly associated with the highest amount of $\mathrm{C} 20: 5 \mathrm{n}-3$ ( $p=0.031)$. CC type of rs41729173 in FABP4 was significantly associated with the lowest amount of C22:2n-6 ( $p=$ 0.047). AG type of rs42187261 in FADS1 was significantly linked to the lowest concentration of C20:4 n-6 ( $p=0.044)$. In the 55 samples, there was only one cattle with all four SNPS types which has 27.9 in $n-6 / n-3$ ratio. This was the third lowest in 55 samples and much lower than the mean value of the total $n-6 / n-3$ ratio $(56.059 \pm 16.180$, Table 1$)$. In conclusion, these four SNPs may have potential as genetic markers to select Hanwoo steers in the aspect of improvement of $n-6 / n-3$ balance in the future.

\section{Competing interests}

No potential conflict of interest relevant to this article was reported.

\section{Funding sources}

This work was supported by Korea Institute of Planning and Evaluation for Technology in Food, Agriculture, Forestry and Fisheries (IPET) through Agri-Bio Industry Technology Development Program, funded by Ministry of Agriculture, Food and Rural Affairs (MAFRA) (316005-5).

\section{Acknowledgements}

Not applicable.

\section{Availability of data and material}

Upon reasonable request, the datasets of this study can be available from the corresponding author. The information about SNPs in the study can be found with accession no. rs41919985, rs41255693, rs41729173, rs42187261, rs136261927 and rs109772589 available at https://www.ncbi.nlm.nih.gov/SNP.

\section{Authors' contributions}

Conceptualization: Beak SH, Lee YS, Bok JD, Kang SK.

Data curation: Beak SH, Lee YS.

Formal analysis: Beak SH, Lee YS, Lee EB.

Methodology: Beak SH, Lee YS, Lee EB, Kim KH, Kim JG, Bok JD, Kang SK.

Software: Beak SH, Lee YS.
Validation: Beak SH, Lee YS, Kim KH, Kim JG, Bok JD, Kang SK. Investigation: Beak SH, Lee YS, Kang SK.

Writing - original draft: Beak SH, Lee YS.

Writing - review \& editing: Beak SH, Lee YS, Lee EB, Kim KH, Kim JG, Bok JD, Kang SK (All authors).

\section{Ethics approval and consent to participate}

The Ethics Committee on the Use of Animals (CEUA) of Embrapa Genetic Resources and Biotechnology approved this study in March of 2013 under the reference number 001/2013.

\section{ORCID}

Seok-Hyeon Beak https://orcid.org/0000-0003-4550-5937 Yoonseok Lee https://orcid.org/0000-0003-4803-5192

Eun Bi Lee https://orcid.org/0000-0001-6184-175X

Kyoung Hoon Kim https://orcid.org/0000-0002-7288-7443

Jong Geun Kim https://orcid.org/0000-0003-4720-1849

Jin Duck Bok https://orcid.org/0000-0002-0955-2923

Sang-Kee Kang https://orcid.org/0000-0002-4751-9841

\section{Supplementary Materials}

Supplementary materials are only available online from: https:// doi.org/10.5187/jast.2019.61.2.69.

\section{References}

1. Simopoulos AP. The importance of the ratio of omega-6/omega-3 essential fatty acids. Biomed Pharmacother. 2002;56:365-79.

2. Daley CA, Abbott A, Doyle PS, Nader GA, Larson S. A review of fatty acid profiles and antioxidant content in grass-fed and grain-fed beef. Nutr J. 2010;9:10.

3. Weill P, Schmitt B, Chesneau G, Daniel N, Safraou F, Legrand P. Effects of introducing linseed in livestock diet on blood fatty acid composition of consumers of animal products. Ann Nutr Metab. 2002;46:182-91.

4. Bourre JM. Where to find omega-3 fatty acids and how feeding animals with diet enriched in omega- 3 fatty acids to increase nutritional value of derived products for human: what is actually useful? J Nutr Health Aging. 2005;9:232-42.

5. Buchanan JW, Reecy JM, Garrick DJ, Duan Q, Beitz DC, Mateescu RG. Genetic parameters and genetic correlations among triacylglycerol and phospholipid fractions in Angus cattle.J Anim Sci. 2015;93:522-8.

6. Dujkova R, Ranganathan Y, Dufek A, Macak J, Bezdicek J. Polymorphic effects of FABP4 and SCD genes on intramuscular fatty acid profiles in longissimus muscle from two cattle breeds. Acta Vet Brno. 2015;84:327-36. 
7. Li C, Aldai N, Vinsky M, Dugan ME, McAllister TA. Association analyses of single nucleotide polymorphisms in bovine stearoyl-CoA desaturase and fatty acid synthase genes with fatty acid composition in commercial cross-bred beef steers. Anim Genet. 2012;43:93-7.

8. Oh D, Lee Y, La B, Yeo J, Chung E, Kim Y, et al. Fatty acid composition of beef is associated with exonic nucleotide variants of the gene encoding FASN. Mol Biol Rep. 2012;39:4083-90.

9. Taniguchi M, Mannen H, Oyama K, Shimakura Y, Oka A, Watanabe $\mathrm{H}$, et al. Differences in stearoyl-CoA desaturase mRNA levels between Japanese Black and Holstein cattle. Livest Prod Sci. 2004;87:215-20.

10. Ibeagha-Awemu EM, Akwanji KA, Beaudoin F, Zhao X. Associations between variants of FADS genes and omega- 3 and omega-6 milk fatty acids of Canadian Holstein cows. BMC Genet. 2014;15:25.

11. Raes K, De Smet S, Demeyer D. Effect of dietary fatty acids on incorporation of long chain polyunsaturated fatty acids and conjugated linoleic acid in lamb, beef and pork meat: a review. Anim Feed Sci Technol. 2004;113:199-221.

12. Folch J, Lees M, Solane Stanley GH. A simple method for the isolation and purification of total lipides from animal tissues. J Biol Chem. 1956;226:497-509.

13. Tanamati A, Oliveira CC, Visentainer JV, Matsushita M, de Souza NE. Comparative study of total lipids in beef using chlorinated solvent and low-toxicity solvent methods. J Am Oil Chem Soc. 2005;82:393-7.

14. Toschi TG, Bendini A, Ricci A, Lercker G. Pressurized solvent extraction of total lipids in poultry meat. Food Chem. 2003;83:551-5.

15. O’Fallon JV, Busboom JR, Nelson ML, Gaskins CT. A direct method for fatty acid methyl ester synthesis: application to wet meat tissues, oils, and feedstuffs. J Anim Sci. 2007;85:1511-21.

16. Ghatak S, Muthukumaran RB, Nachimuthu SK. A simple method of genomic DNA extraction from human samples for PCR-RFLP analysis. J Biomol Tech. 2013;24:224-31.

17. National Center for Biotechnology Information. US National Library of Medicine, Rockville Pike. https://blast.ncbi.nlm. nih.gov/Blast.cgi. Accessed 20 Nov 2018.

18. Vincze T, Posfai J, Roberts RJ. NEBcutter: a program to cleave DNA with restriction enzymes. Nucleic Acids Res. 2003:31:3688-91.

19. Mannen H. Identification and utilization of genes associated with beef qualities. Anim Sci J. 2011;82:1-7.

20. Guillou H, Zadravec D, Martin PGP, Jacobsson A. The key roles of elongases and desaturases in mammalian fatty acid metabolism: Insights from transgenic mice. Prog Lipid Res. 2010;49:186-99.

21. Bhuiyan MSA, Yu SL, Jeon JT, Yoon D, Cho YM, Park EW, et al. DNA polymorphisms in SREBF1 and FASN genes affect fatty acid composition in Korean cattle (Hanwoo). Asian-Australas J Anim Sci. 2009;22:765-73.

22. Hirschhorn JN, Daly MJ. Genome-wide association studies for common diseases and complex traits. Nat Rev Genet. 2005;6:95-108.

23. Oh DY, Jin MH, Lee YS, Ha JJ, Kim BK, Yeo JS, et al. Identification of stearoyl-CoA desaturase (SCD) gene interactions in Korean native cattle based on the multifactor-dimensionality reduction method. Asian-Australas J Anim Sci. 2013;26:1218-28.

24. Calder PC. Omega-3 polyunsaturated fatty acids and inflammatory processes: nutrition or pharmacology? Br J Clin Pharmacol. 2013;75:645-62.

25. Harika RK, Eilander A, Alssema M, Osendarp SJM, Zock PL. Intake of fatty acids in general populations worldwide does not meet dietary recommendations to prevent coronary heart disease: a systematic review of data from 40 countries. Ann Nutr Metab. 2013;63:229-38.

26. Hulbert AJ, Turner N, Storlien LH, Else PL. Dietary fats and membrane function: implications for metabolism and disease. Biol Rev Camb Philos Soc. 2005;80:155-69.

27. Kris-Etherton PM, Taylor DS, Yu-Poth S, Huth P, Moriarty K, Fishell V, et al. Polyunsaturated fatty acids in the food chain in the United States. Am J Clin Nutr. 2000;71:179S-88S.

28. Roy R, Taourit S, Zaragoza P, Eggen A, Rodellar C. Genomic structure and alternative transcript of bovine fatty acid synthase gene (FASN): comparative analysis of the FASN gene between monogastric and ruminant species. Cytogenet $\mathrm{Ge}-$ nome Res. 2005;111:65-73.

29. Scollan ND, Choi NJ, Kurt E, Fisher AV, Enser M, Wood JD. Manipulating the fatty acid composition of muscle and adipose tissue in beef cattle. Br J Nutr. 2001;85:115-24.

30. Simopoulos AP. The importance of the omega-6/omega-3 fatty acid ratio in cardiovascular disease and other chronic diseases. Exp Biol Med (Maywood). 2008;233:674-88.

31. Simopoulos AP. Importance of the omega-6/omega-3 balance in health and disease: evolutionary aspects of diet. World Rev Nutr Diet. 2011;102:10-21.

32. Sugano M, Hirahara F. Polyunsaturated fatty acids in the food chain in Japan. Am J Clin Nutr. 2000;71:189S-96S.

33. Zhang S, Knight TJ, Reecy JM, Beitz DC. DNA polymorphisms in bovine fatty acid synthase are associated with beef fatty acid composition. Anim Genet. 2008;39:62-70. 


\section{Supplementary Materials}

Table S1. Primer sequence and information on six candidate SNPs used in this study

\begin{tabular}{|c|c|c|c|c|c|c|}
\hline SNP (gene) & Primer sequences $\left(5^{\prime} \rightarrow 3^{\prime}\right)$ & $\begin{array}{l}\text { Product size } \\
\text { (bp) }\end{array}$ & Allele type (bp) & $\operatorname{Tm}\left({ }^{\circ} \mathrm{C}\right)$ & $\begin{array}{l}\text { Restriction } \\
\text { enzyme }\end{array}$ & Reference \\
\hline $\begin{array}{l}\text { rs41919985 } \\
\text { (FASN) }\end{array}$ & $\begin{array}{l}\mathrm{F}: \text { : CTTCACAGAGCTGACGGACT } \\
\mathrm{R}: \text { CTTAGCCCTCGTCTGCAGG }\end{array}$ & 311 & $\begin{array}{c}\text { GG: } 311 \\
\text { GA: } 311 / 196 / 114 \\
\text { AA: } 196 / 44\end{array}$ & 65 & Msc I & Li et al., 2012 \\
\hline $\begin{array}{l}\text { rs } 41255693 \\
\text { (SCD) }\end{array}$ & $\begin{array}{l}\mathrm{F}: \text { ACCTGGTGTCCTGTTGTTGTGCTTC } \\
\mathrm{R}: \text { GATGACCCACTCTTCTATTTACGC }\end{array}$ & 569 & $\begin{array}{c}\text { TT: } 406 / 163 \\
\text { TC: } 406 / 348 / 163 / 58 \\
\text { CC: } 348 / 163 / 58\end{array}$ & 54.5 & Aci I & \\
\hline $\begin{array}{l}\text { rs41729173 } \\
\text { (FABP4) }\end{array}$ & $\begin{array}{l}\mathrm{F}: \text { ATATAGTCCATAGGGTGGCAAAGA } \\
\mathrm{R}: \text { AACCTCTCTTTGAATTCTCCATTCT }\end{array}$ & 452 & $\begin{array}{c}\text { CC: } 452 \\
\text { CG: } 452 / 352 / 100 \\
\text { GG: } 352 / 100\end{array}$ & 61 & MspA1 I & Dujková et al., 2015 \\
\hline $\begin{array}{l}\text { rs42187261 } \\
\text { (FADS1) }\end{array}$ & $\begin{array}{l}\mathrm{F}: \text { : CTGGCACCTGTGAAGGAAAT } \\
\mathrm{R}: \text { CTGTGTAACCCACACAAACC }\end{array}$ & 523 & - & 60 & - & $\begin{array}{l}\text { Ibeagha-Awemu et al., } \\
2014\end{array}$ \\
\hline $\begin{array}{l}\text { rs136261927 } \\
\text { (FADS1) }\end{array}$ & $\begin{array}{l}\mathrm{F}: \text { AGCGGGAGAAATGGAAGGTG } \\
\mathrm{R}: \text { TCATGAAGGCCAACCCTGTC }\end{array}$ & 311 & $\begin{array}{c}\text { AA: } 311 \\
\text { GA: } 311 / 216 / 95 \\
\text { GG: } 216 / 95\end{array}$ & 61 & Acil & \\
\hline $\begin{array}{l}\text { rs109772589 } \\
\text { (FADS2) }\end{array}$ & $\begin{array}{l}\mathrm{F}: \text { ATGGGACAAAGAGGGGTTGG } \\
\mathrm{R}: \text { GCGCTGAACAAGGAAGTGAGA }\end{array}$ & 380 & $\begin{array}{c}\text { AA: } 380 \\
\text { AG: } 380 / 224 / 156 \\
\text { GG: } 224 / 156\end{array}$ & 61 & Fau I & \\
\hline
\end{tabular}

SNP, single nucleotide polymorphism; bp, base pair; Tm, melting temperature; FASN, fatty acid synthase; SCD, stearoyl-CoA desaturase; FABP, fatty acid binding protein; FADS, fatty acid desaturase. 


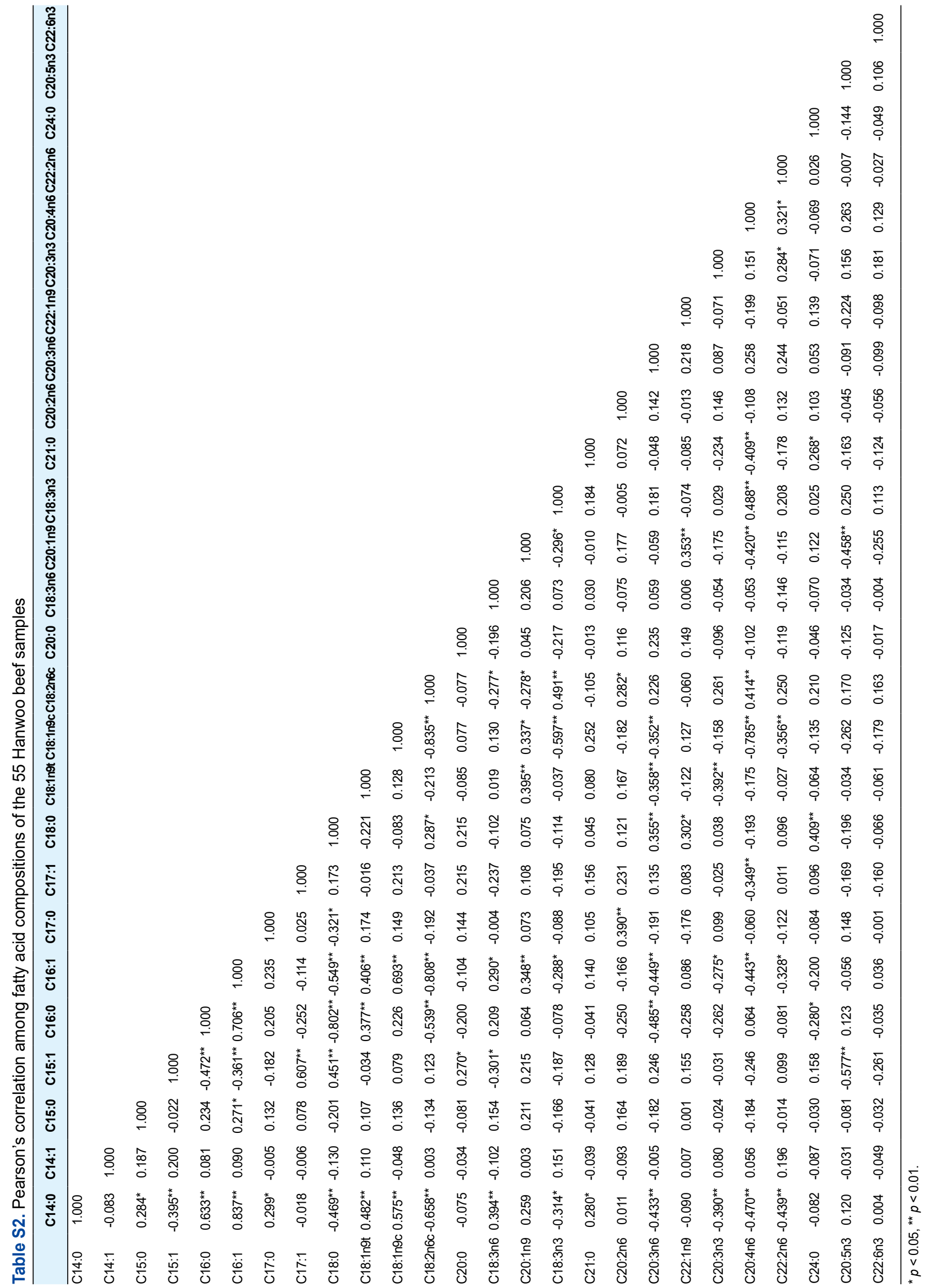


Table S3. The association between genotypes and omega fatty acid composition of the 55 Hanwoo in comparison with the references

\begin{tabular}{|c|c|c|c|c|c|c|c|c|c|}
\hline \multirow[b]{2}{*}{ SNP (gene) } & \multirow[b]{2}{*}{ Reference } & \multirow[b]{2}{*}{ Fatty acid } & \multirow[b]{2}{*}{ SNP type } & \multicolumn{2}{|c|}{$\mathbf{n}$} & \multicolumn{2}{|c|}{ Mean (\%) } & \multicolumn{2}{|r|}{$p$-value } \\
\hline & & & & $\begin{array}{l}\text { This } \\
\text { study }\end{array}$ & Refenece & This study & Refenece & $\begin{array}{l}\text { This } \\
\text { study }\end{array}$ & $\begin{array}{c}\text { Refenece } \\
\text { (cattle breed) }\end{array}$ \\
\hline \multirow{3}{*}{$\begin{array}{l}\text { rs419199859 } \\
\text { (FASN) }\end{array}$} & \multirow[t]{6}{*}{ Li et al., 2012} & \multirow[t]{3}{*}{$C 20: 3 n-6$} & AA & - & 64 & - & $0.071 \pm 0.003$ & \multirow[t]{3}{*}{0.553} & \multirow{3}{*}{$\begin{array}{c}0.04 \\
\text { (Canadian } \\
\text { Commercial) }\end{array}$} \\
\hline & & & GA & 17 & 114 & $4.921 \pm 0.304$ & $0.074 \pm 0.002$ & & \\
\hline & & & GG & 38 & 45 & $5.116 \pm 0.171$ & $0.079 \pm 0.003$ & & \\
\hline \multirow{3}{*}{$\begin{array}{l}\text { rs41255693 } \\
\text { (SCD) }\end{array}$} & & \multirow[t]{3}{*}{$C 20: 2$ n-6 } & $\mathrm{TT}$ & 12 & 26 & $0.287 \pm 0.049$ & $0.021 \pm 0.001$ & \multirow[t]{3}{*}{0.430} & \multirow{3}{*}{$\begin{array}{c}0.011 \\
\text { (Canadian } \\
\text { Commercial) }\end{array}$} \\
\hline & & & $\mathrm{TC}$ & 32 & 110 & $0.281 \pm 0.022$ & $0.019 \pm 0.001$ & & \\
\hline & & & $\mathrm{CC}$ & 11 & 87 & $0.228 \pm 0.012$ & $0.017 \pm 0.001$ & & \\
\hline \multirow{12}{*}{$\begin{array}{l}\text { rs41729173 } \\
\text { (FABP4) }\end{array}$} & \multirow[t]{12}{*}{ Dujková et al., 2015} & \multirow[t]{3}{*}{$C 18: 2 n-6$} & GG & 3 & 2 & $29.350 \pm 3.351$ & $18.88 \pm 2.83$ & \multirow[t]{3}{*}{0.747} & \multirow{3}{*}{$\begin{array}{c}0.031 \\
\text { (Aberdeen Angus) }\end{array}$} \\
\hline & & & CG & 19 & 8 & $29.549 \pm 0.737$ & $17.91 \pm 1.42$ & & \\
\hline & & & $\mathrm{CC}$ & 33 & 7 & $28.554 \pm 0.898$ & $12.20 \pm 1.51$ & & \\
\hline & & \multirow[t]{3}{*}{ C20:4 n-6 } & GG & 3 & 1 & $13.697 \pm 0.976$ & - & \multirow[t]{3}{*}{0.566} & \multirow{3}{*}{$\begin{array}{c}0.044 \\
\text { (Blonde } \\
\text { d'Aqquitaine) }\end{array}$} \\
\hline & & & CG & 19 & 4 & $14.925 \pm 0.503$ & $3.80 \pm 0.56$ & & \\
\hline & & & $\mathrm{CC}$ & 33 & 11 & $14.139 \pm 0.543$ & $5.25 \pm 0.34$ & & \\
\hline & & \multirow[t]{3}{*}{ C20:5 n-3 } & GG & 3 & 1 & $0.214 \pm 0.049$ & - & \multirow[t]{3}{*}{0.329} & \multirow{3}{*}{$\begin{array}{c}0.05 \\
\text { (Blonde } \\
\text { d'Aquitaine) }\end{array}$} \\
\hline & & & CG & 19 & 4 & $0.388 \pm 0.073$ & $0.56 \pm 0.13$ & & \\
\hline & & & $\mathrm{CC}$ & 33 & 11 & $0.310 \pm 0.028$ & $0.90 \pm 0.08$ & & \\
\hline & & \multirow[t]{3}{*}{ Total n6/n3 } & GG & 3 & 1 & $70.731 \pm 5.774$ & - & \multirow[t]{3}{*}{0.206} & \multirow{3}{*}{$\begin{array}{c}0.031 \\
\text { (Blonde } \\
\text { d'Aquitaine) }\end{array}$} \\
\hline & & & CG & 19 & 4 & $52.979 \pm 3.802$ & $11.06 \pm 1.19$ & & \\
\hline & & & $\mathrm{CC}$ & 33 & 11 & $56.498 \pm 2.780$ & $6.72 \pm 1.11$ & & \\
\hline \multirow{3}{*}{$\begin{array}{l}\text { rs42187261 } \\
\text { (FADS1) }\end{array}$} & Ibeagha-Awemu et al., & C20:5 n-3 & AA & 28 & 129 & $0.384 \pm 0.053$ & $0.0370 \pm 0.001$ & 0.165 & 0.029 \\
\hline & & & $A G$ & 21 & 209 & $0.259 \pm 0.030$ & $0.0330 \pm 0.001$ & & $\begin{array}{l}\text { (Canadian } \\
\text { Holstein) }\end{array}$ \\
\hline & & & GG & 6 & 70 & $0.345 \pm 0.056$ & $0.0360 \pm 0.001$ & & \\
\hline rs136261927 & & C20:3 n-6 & AA & 15 & 12 & $5.377 \pm 0.127$ & $0.0750 \pm 0.007$ & 0.049 & \\
\hline & & & GA & 23 & 135 & $4.639 \pm 0.316$ & $0.0870 \pm 0.007$ & & Holstein) \\
\hline & & & GG & 17 & 275 & $5.336 \pm 0.148$ & $0.0950 \pm 0.007$ & & \\
\hline
\end{tabular}

SNP, single nucleotide polymorphism; $n$, number of animals; FASN, fatty acid synthase; SCD, stearoyl-CoA desaturase; FABP, fatty acid binding protein; FADS, fatty acid desaturase. 
Table S4. The association between genotypes and omega fatty acid composition showing some tendency

\begin{tabular}{|c|c|c|c|c|c|}
\hline SNP (gene) & Fatty acid & SNP type & $n$ & Mean (\%) & $p$-value \\
\hline \multirow{12}{*}{$\begin{array}{l}\text { rs41255693 } \\
\text { (SCD) }\end{array}$} & \multirow[t]{3}{*}{$C 18: 3 n-6$} & TT & 12 & $0.285 \pm 0.042$ & \multirow[t]{3}{*}{0.418} \\
\hline & & TC & 32 & $0.254 \pm 0.023$ & \\
\hline & & $\mathrm{CC}$ & 11 & $0.219 \pm 0.008$ & \\
\hline & \multirow[t]{3}{*}{ C18:3n-3 } & $\mathrm{TT}$ & 12 & $0.370 \pm 0.024$ & \multirow[t]{3}{*}{0.395} \\
\hline & & $\mathrm{TC}$ & 32 & $0.402 \pm 0.018$ & \\
\hline & & $\mathrm{CC}$ & 11 & $0.427 \pm 0.033$ & \\
\hline & \multirow[t]{3}{*}{$\mathrm{C} 20: 3 \mathrm{n}-3$} & $\mathrm{TT}$ & 12 & $0.093 \pm 0.010$ & \multirow[t]{3}{*}{0.784} \\
\hline & & $\mathrm{TC}$ & 32 & $0.100 \pm 0.005$ & \\
\hline & & $\mathrm{CC}$ & 11 & $0.100 \pm 0.004$ & \\
\hline & \multirow[t]{3}{*}{ total n6/n3 } & $\mathrm{TT}$ & 12 & $53.820 \pm 5.757$ & \multirow[t]{3}{*}{0.863} \\
\hline & & $\mathrm{TC}$ & 32 & $56.527 \pm 2.747$ & \\
\hline & & $\mathrm{CC}$ & 11 & $57.140 \pm 4.468$ & \\
\hline \multirow{6}{*}{$\begin{array}{c}\text { rs42187261 } \\
\text { (FADS1) }\end{array}$} & \multirow[t]{3}{*}{ C18:3n-6 } & AA & 28 & $0.230 \pm 0.016$ & \multirow[t]{3}{*}{0.191} \\
\hline & & $A G$ & 21 & $0.268 \pm 0.031$ & \\
\hline & & GG & 6 & $0.318 \pm 0.055$ & \\
\hline & \multirow[t]{3}{*}{$C 22: 2 n-6$} & $A A$ & 28 & $0.111 \pm 0.005$ & \multirow[t]{3}{*}{0.766} \\
\hline & & $A G$ & 21 & $0.106 \pm 0.008$ & \\
\hline & & GG & 6 & $0.101 \pm 0.021$ & \\
\hline \multirow{6}{*}{$\begin{array}{l}\text { rs136261927 } \\
\text { (FADS1) }\end{array}$} & \multirow[t]{3}{*}{ C18:3 n-6 } & AA & 15 & $0.237 \pm 0.027$ & \multirow[t]{3}{*}{0.492} \\
\hline & & GA & 23 & $0.243 \pm 0.022$ & \\
\hline & & GG & 17 & $0.282 \pm 0.036$ & \\
\hline & \multirow[t]{3}{*}{ C20:5 n-3 } & $A A$ & 15 & $0.377 \pm 0.092$ & \multirow[t]{3}{*}{0.621} \\
\hline & & GA & 23 & $0.327 \pm 0.033$ & \\
\hline & & GG & 17 & $0.298 \pm 0.040$ & \\
\hline
\end{tabular}

SNP, single nucleotide polymorphism; $n$, number of animals; SCD, stearoyl-CoA desaturase; FABP, fatty acid binding protein; FADS, fatty acid desaturase. 